Materials Science: Oral 8

\title{
Salt weathering of limestones: susceptibility of petrographical features (SEM study)
}

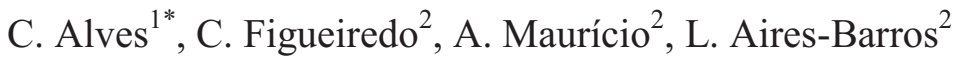 \\ ${ }^{1}$ Centro de Investigação Geológica, Ordenamento e Valorização de Recursos, Universidade do Minho, \\ Campus de Gualtar, 4710-057 Braga, Portugal*corresponding author, email :casaix@dct.uminho.pt \\ ${ }^{2}$ Centro de Petrologia e Geoquímica, Instituto Superior Técnico, Av. Rovisco Pais 1, 1049-001 Lisbon, \\ Portugal
}

Scanning electron microscopy (SEM) studies of stone decay can give important contributions in the understanding of the susceptibility of petrographic features of rocks to salt weathering. Here are presented results of SEM studies in limestones (grainstones with the commercial designations of Semirijo and Moca Creme and a travertine, geological details in [1-4]) submitted to salt weathering tests according to the EN 12370 using sodium sulphate. The SEM observation before and after the tests allows the discussion of the petrographical characteristics of these rocks that contribute to erosive decay under salt weathering. In the case of the grainstones the texture can be described in general as allochemical particles cemented by sparry calcite (Fig. 1a) and it is visible from the preparation of the polished surfaces the interface between the sparry cement and the allochemical components. After the salt weathering tests, SEM studies show (Fig. 1b) that the sparry cement presents extensive fissuring and separation between the grains and sparry cement. The observations of disaggregation products of the grainstones showed an important amount of apparently intact grains [1,2]. These results are similar to those observed by [5] with the sparry cement being affect by salt crystallisation and lesser impact on the grains. Fragments from small cubes of the grainstones also subjected to salt weathering cycles without the final water cleaning were also studied allowing to observe the presence of sodium sulphate in the interface between allochemical grains and the sparry cement (Fig. 1c,d). In the case of the travertine, specimens show heterogeneous patterns of erosion that seem related to the heterogeneous texture of this rock, with more terrigenous (specially clay-rich) portions favouring higher erosive susceptibility $[1,2]$. The presence of clays has frequently being associated with salt weathering susceptibility in limestones [6]. In Fig. 1e can be observed the heterogeneity of the polished surface, with the more irregular portions showing a chemical spectra (Fig. 1f) indicative of the terrigenous component and showing also the presence of sodium and sulphate related to the weathering solutions.

The authors acknowledge the support of the Fundação para a Ciência e Tecnologia (POCTI/CTA/44940/2002; PEst-OE/CTE/UI0697/2011 and Pest-OE/CTE/UI0098/2011, funding by the European Union and national budget of the Portuguese Republic). Acknowledgments to Eng. Teresa Luís, Eng. Sónia Pereira and Enterprise Mármores Galrão for the rock blocks.

1. Alves C., Figueiredo C., Sequeira Braga M. A., Maurício A., Aires-Barros L. IRF'2009, 2009, http://paginas.fe.up.pt/clme/IRF2009/PROCEEDINGS/PAPERS/P0317.pdf

2. Alves C, Figueiredo C, Sequeira Braga MA, Maurício A, Aires-Barros L. Env Earth Sci

2011;63:1511-1527.

3. Figueiredo C, Folha R, Maurício A, Alves C, Aires-Barros L. Geol Soc Spec Pub 2010;333:153-163.

4. Figueiredo C, Folha R, Maurício A, Alves C, Aires-Barros L. Geol Soc Spec Pub 2010;331:157-169.

5. Rodriguez-Navarro C, Doehne E. Earth Surf Proc Landf 1999;24:191-209.

6. Ordóñez S, Fort R, García del Cura MA. Q J Eng Geol 1997;30:221-230 


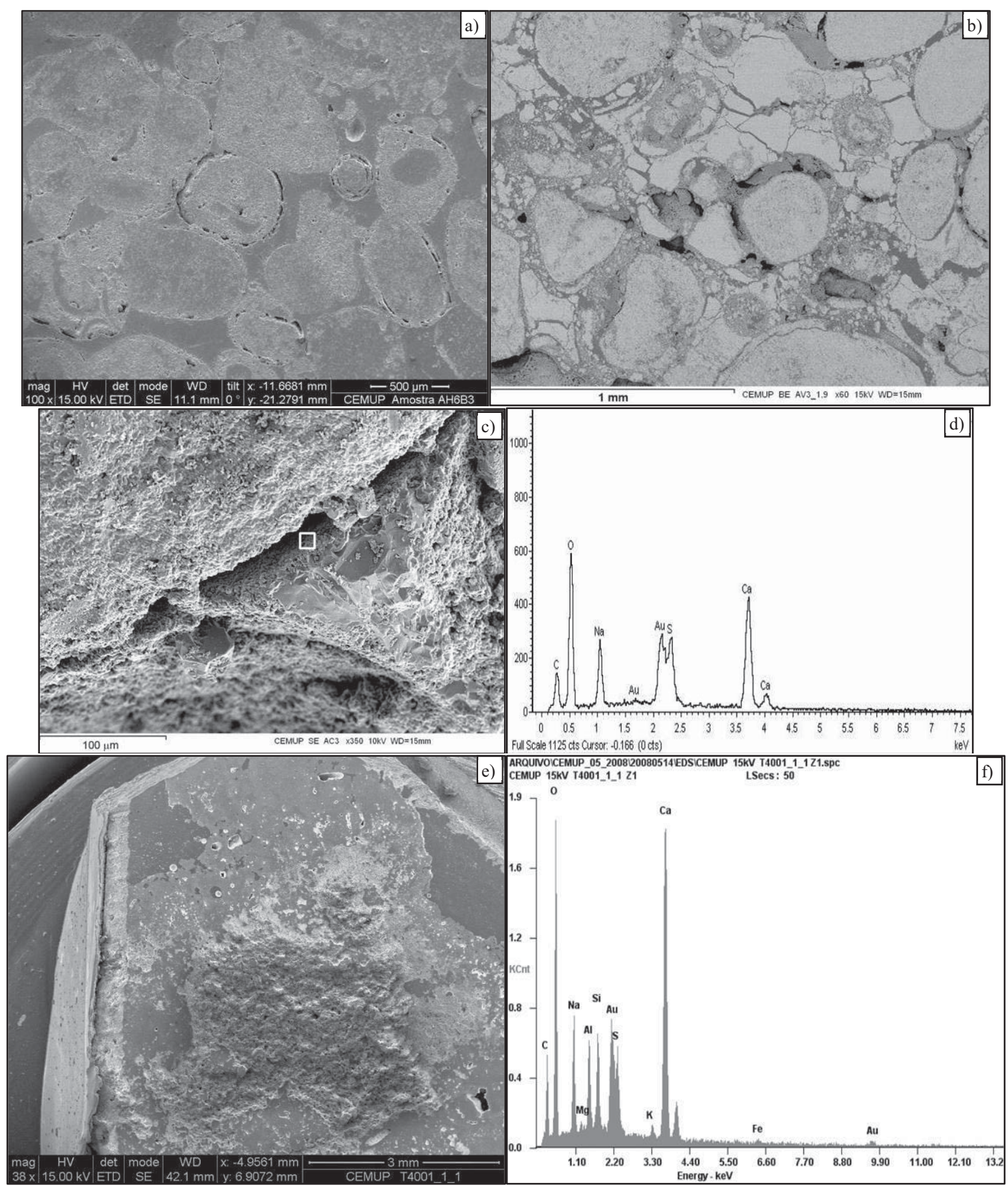

Fig. 1 - SEM studies of the susceptibility of limestone petrographical features to salt weathering: a) grainstone texture before salt weathering tests showing grains cemented by sparry calcite, b) intense fissuring of sparry calcite and grains separation after salt weathering test on grainstones; c) sodium sulphate in the interface between sparry cement and grains; d) spectrum of c), e) heterogeneous surface of travertine after salt weathering test; f) spectrum of more irregular area of travertine after salt weathering indicating terrigenous fraction and sodium sulphate. SEM studies performed at CEMUP laboratory (University of Oporto, Portugal). 